\title{
Practical Discussion on the Curriculum Ideology and Politics Teaching Reform of "Bridge Engineering"
}

\author{
Yiming Yang ${ }^{1}$, Xinzhong Wang ${ }^{1} \&$ Huang Tang ${ }^{1}$ \\ ${ }^{1}$ College of Civil Engineering, Hunan City University, Yiyang, China \\ Correspondence: Yiming Yang, College of Civil Engineering, Hunan City University, 518 Yingbin East Road, \\ Yiyang 413000, Hunan, China. E-mail: yimingyang91@ outlook.com
}

Received: January 15, 2022

Accepted: February 15, 2022

Online Published: February 27, 2022

doi:10.20849/aes.v7i1.1015

URL: https://doi.org/10.20849/aes.v7i1.1015

Funding: Teaching reform project of Provincial Education Department of Hunan (Research on the evaluation of "golden courses" in applied undergraduate colleges based on fuzzy analytic hierarchy process (FAHP)).

\begin{abstract}
As ideological and political element is an essential element in the entire education process, it is of great significance to foster virtues and promote rounded development of people, improve teaching outcomes, and help students majoring in civil engineering receive well-rounded education. This paper takes "Bridge Engineering", one of the core courses of civil engineering, as an example, and explores the teaching reform and practices around the current inadequacies in incorporating ideological and political elements into university education, in an effort to provide reference for the ideological and political teaching reform and practice of the course "Bridge Engineering".
\end{abstract}

Keywords: curriculum ideology and politics, bridge engineering, teaching reform, practice

\section{Introduction}

The work of integrating ideological and political elements into the university education provides a new platform and mechanism for cultivating talents and fostering virtues under the new circumstances. Chinese president $\mathrm{Xi}$ Jinping, also General Secretary of the Communist Party of China (CPC) Central Committee, stressed the importance at a meeting on ideological and political work in China's universities and colleges. He said universities and colleges should make full use of classroom teaching, ensure higher education adhere to correct political orientation, and strengthen teaching on ideological and political theory through reforms to make ideological and political education more appealing2-4. Indoctrinating students to have certain ideological beliefs can neither be a solution to fully carrying out the reform nor meet students' needs for learning professional knowledge5, so the key tasks for such reform that teachers need to explore lies in how to enable students to be more motivated to improve their ideological quality and political awareness when learning knowledge from major-focused courses. It should be noted that ideological and political education is not equal to simply presenting some cases to students; rather, we should make sure "the cases have to fit well with class teaching" 4 . To that end, ideological and political education depends on theoretical teaching given by a few political teachers. What's more, all teachers in charge of major-focused courses shall participate in ideological and political education and work hard to set up a system. Therefore, the major-focused knowledge is integrated with ideological and political education. How to integrate is a topic worth exploring further. When passing the major-focused knowledge on to students, teachers are also expected to integrate such ideological and political elements as the correct outlook on life, the sense of social responsibility, patriotism, loving the Party and national rejuvenation with the entire teaching process. The socialist core values should run through the whole process of college education6. Such integration will not only help consolidate students' major-related theoretical skills, but also help them foster a correct outlook on life and sense of values and always cherish deep love for our great country and sense of responsibility, in order to cultivate students to be young progressives with selfless devotion to forge ahead.

How to integrate the ideological and political education into the teaching process of civil engineering and how to figure out effective teaching design in this regard are pressing issues worth serious consideration. This paper 
takes one of the core courses for civil engineering - "Bridge Engineering" as an example, analyzes the current inadequacies in incorporating ideological and political elements into the teaching of this course, and explores feasible reform and practices, in an attempt to provide reference for improving the ideological and political education in the process of giving other courses related to STEM (Science, Technology, Engineering and Mathematics).

\section{Analysis Into the Current Ideological and Political Education in the Course of Bridge Engineering}

As one of the core courses for civil engineering, "Bridge Engineering" aims to give students a whole picture of bridge engineering and encourage them to use the knowledge learned from multiple courses to complete tasks such as bridge design and evaluation7. Meanwhile, through the teaching, students are cultivated to become outstanding civil engineers that can have a strong work ethic, foster respect for science, love our great country and champion the pursuit of fine workmanship. At present, the integration of ideological and political education into this course is under exploration, and some typical problems listed below are in dire need of solutions.

\subsection{Difficulties in Integration}

Most STEM teachers fail to accumulate sufficient knowledge necessary to give ideological and political education. Besides, the long-held stereotypes that only the teachers of ideological and political theory courses are responsible for cultivating students' moral integrity still die hard in the minds of some STEM teachers, so they fail to attach enough importance and find it difficult to integrate ideological and political education into their teaching process. Although teachers of the "Bridge Engineering" course are qualified to deliver major-focused knowledge to their students, many are besieged with the difficulty of incorporating ideological and political education into their classes due to insufficient liberal-arts knowledge. Some teachers have already got down to seek approaches for better integration, only to find that their exploration bring about limited effects. In their teaching practices, ideological and political elements are not well integrated with the major-focused knowledge, thus greatly reduce the positive impacts of ideological and political education.

\subsection{Monotonous Teaching Models}

Most civil engineering teachers in colleges and universities are masters and doctoral degree holders, which means they have received solid training on carrying out scientific researches, but they are inexperienced in teaching and are more familiar with traditional teaching models. Besides, most civil engineering teachers used to be STEM majors or graduated from STEM universities, so they haven't received systematic training on teaching as those graduating from normal universities. As a result, when they teach "Bridge Engineering", they don't develop a deep understanding of the teaching concepts, models and methods, and fail to adopt diversified teaching patterns.

\subsection{Assessment Mechanism Not Put in Place}

In the process of making teaching plans for the course "Bridge Engineering" and evaluating the teaching effects, most only focus on whether the course system is reasonable, whether the teaching contents conform to the syllabus, and whether the practice sessions proceed as scheduled. They evaluate the effectiveness of classroom teaching and talent cultivation with a set of relatively simple, easy-to-quantify and easy-to-operate indicators. Many teachers have emphasized that ideological and political education play a big part in teaching and evaluation process, and they also incorporated various ideological and political elements, including morality integrity, scientific literacy and humanistic care in the course "Bridge Engineering". However, most of such attempts cannot be assessed by scientific evaluation standards. Even worse, very few approaches miss out the evaluation process, which on the one hand fail to highlight the purpose of the ideological and political education, and meanwhile discourage the efforts to map out further measures for improvement and reduce the effectiveness of such measures. Finally, the ideological and political education cannot play its role to the full extent.

\section{Reform and Practice Exploration}

In order to better achieve the teaching objectives of the course "Bridge Engineering", this paper analyzes, summarizes and reflects on some common problems concerning the integration of ideological and political education, and seeks to find solutions.

\subsection{Enhancing Teachers' Competence in Ideological and Political Education}

The key to guaranteeing the quality of ideological and political education in major-focused courses teaching lies in strengthening work on building the teaching workforce and raise the teachers' awareness and understanding of ideological and political theories. Therefore, relevant institutions should carry out more training on improving teachers' competence to give better ideological and political education in their major-focused courses, and enable 
them to fully understand and pay attention to the latest development and trends related to ideological and political education through political theory training and other means. At the same time, the training on better integrating ideological and political education into the teaching process of "Bridge Engineering" should be delivered. During the training session, teachers can know more relevant teaching experience and methods, and exchange ideas with ideological and political theory teachers. We can also encourage the teachers in charge of major-focused courses to prepare lessons, give lessons and share resources together with the ideological and political theory teachers, and we can even paired up those who find it difficult to integrate ideological and political elements into their classroom teaching with the teachers of ideological and political theory, so the overall competence of "Bridge Engineering" teachers in giving quality ideological and political education will be enhanced. In addition, teachers of major-focused courses should be encouraged to optimize or change their outdated teaching methods, and try to integrate various ideological and political elements into diversified teaching methods such as flipped classroom and case studies, so as to strengthen their competence in give quality ideological and political education.

\subsection{Reforming Teaching Models}

The course "Bridge Engineering" is featured with heavy teaching load and complex teaching content. If we intend to integrate the ideological and political elements into classroom teaching, traditional teaching models cannot help achieve the teaching objectives, i.e., students can receive major-focused knowledge and meanwhile improve their moral characteristics and humanistic quality. Therefore, teachers can turn to the application of the online and offline interactive teaching and make full use of teaching resources available on the MOOCs launched by other universities on various platforms. What's more, teachers can also set up their own resource libraries to enable students to preview the materials concerning ideological and political education as well as the videos recording the on-site bridge construction. In this way, students can both learn major-focused knowledge and meanwhile enhance their moral integrity. When students preview the video resources ahead of classes and exchange their opinions during classroom discussion, they can better foster virtues.

\subsection{Putting in Place a Sound and Long-Term Mechanism}

Improving the long-term operation mechanism featuring the integration of ideological education into the entire teaching process covers two areas: establishing a scientific and reasonable evaluation system and an incentive mechanism. The former is a necessary condition for testing the effectiveness of the ideological and political education during major-focused classes, and also serves as the basis for formulating other measures for improvement. In this regard, universities and colleges are expected to reform the methods currently used to evaluate teachers' education and students learning. Guiding students to have correct outlook and fostering virtues should also be included in the assessment indicators. The evaluation on the teaching effectiveness of ideological and political education should be given regularly, and the final assessment and the phased assessment should be placed equal emphasis. Then, a long-term mechanism that assessment can ensure ideological and political education better fit in major-focused teaching will be set up. At the same time, we should know well that the above-mentioned reform cannot be accomplished in one stroke and we cannot rest on our laurels indefinitely once existing problems are solved, in an effort to ensure the mechanism can function well all the time.

\section{Conclusion}

In the process of integrating the ideological and political elements into the teaching of "Bridge Engineering", more efforts should be urged to enhance teachers' competence, reform the teaching models, and put in place a long-term mechanism to help students gradually promote patriotism. These efforts will foster a strong sense of national dignity and confidence, enhance the students' love for their majors, and cultivate their aesthetic ability. In this way, the students will enhance their capability to appreciate and create beauty, better practice socialist core values, and comprehensively improve their overall quality.

\section{References}

Cheng, J.-J. (2020). On the Teaching Practice and Connotation Exploration of Integrating Ideological and Political Education into the Course 'Soil Mechanics'. Journal of Bingtuan Education Institute, 30(5), 25-28.

Jiang, S.-H., Xia, C.-W., Zhang, H.-L., Huang, F.-F., \& Liu, W.-P. (2021). Exploration into the Teaching Methods of Integrating Ideological and Political Education into the Course 'Soil Mechanics'. Journal of Architectural Education in Institutions of Higher Learning, 30(6), 81-86.

Lin, W., Xue, X.-H., Li, C.-M., \& Lin, Y.-Z. (2021). The Practice and Innovation of Ideological and Political Education in the Course 'Construction and Calculation for Railway and Highway'. Anhui Architecture, 28(11), 114-116. 
Pan, L. (2018). Research into the Practice of Integrating Ideology and Political Education in STEM Majors_-Taking ‘Advanced WEB Development Technology’ As an Example. Young Society, 33, 107.

Sun, J., \& Peng, Q. (2021). Practice and Exploration in Integrating Ideological and Political Education into the Teaching Process of 'Bridge Engineering' under the New STEM Background. Journal of Zhejiang Business Technology Institute, 20(2), 44-47.

Xi Jinping stressed at a Meeting on Ideological and Political Work in China's Universities and Colleges: Ideological Work in Colleges Should Be Integrated into the Entire Education Process and Usher in New Prospects of the Development of China's Higher Education. (2017). SHIJIAN, 2, 30-31.

Zhu, X.-Q., Song, A.-H., \& Wang, X. (2020). Research and Practice in the Integration of Ideological and Political Education in Soil Mechanics Courses. Education Forum, 27, 80-81.

\section{Copyrights}

Copyright for this article is retained by the author(s), with first publication rights granted to the journal.

This is an open-access article distributed under the terms and conditions of the Creative Commons Attribution license (http://creativecommons.org/licenses/by/4.0/). 